\title{
Eco-print on Recycle Paper/ Fabrics as Main Products of Business Development Program of Intellectual Property Campus of Universitas Sumatera Utara
}

\author{
Arif Nuryawan ${ }^{1,2 *}$, Iwan Risnasari', Arif Irwansyah ${ }^{3}$, Wahyuni Pulungan ${ }^{4}$, \\ Artah Sasta Sinaga ${ }^{1}$, Feby Yanti Emilda Ginting ${ }^{1}$, Mesrayanti Munthe ${ }^{5}$ \\ ${ }^{I}$ Department of Forest Products Technology, Faculty of Forestry, Universitas Sumatera Utara, Medan, \\ North Sumatra, Indonesia. \\ ${ }^{2}$ Integrated Research Laboratory, Universitas Sumatera Utara, Medan, North Sumatra, Indonesia. \\ ${ }^{3}$ Workshop of Nauli Apik USU Jl. Amaliun No.68A/ 136 Medan, Indonesia \\ ${ }^{4}$ Forest Products Laboratory, Faculty of Forestry, Universitas Sumatera Utara, Medan, Indonesia \\ ${ }^{5}$ Mesra Fabric, Jl. Dwikora No. 11 Setia Budi, Medan, Indonesia
}

\begin{abstract}
The purpose of this work is to provide seminar needs (seminar kit) as compliments of seminar or symposium held by university including Universitas Sumatera Utara (USU). Method of this activity included launching of our main products, namely eco-print both on paper and on fabric. In this work, eco-print products on recycle papers was used as exclusive block-note covers while eco-print products on fabric were used as tote-bag materials. There were two advantages of using these products, firstly: they were made of natural ingredients without chemical synthetic materials; and secondly the products were designed specifically; one product was not similar with the others. This activity involved two partners, namely a recycle-paper producer and a tailor who make tote-bag. Result on progress of this activity was an order for seminar kit through exhibition. During the evaluation of this project it was found that Nauli Apik USU, as a seminar kit's producer, still depends on workers whom working manually and having individual skill. In the future, management of production should be improved.
\end{abstract}

Keywords: Eco-print, Fabric, Production management, Recycle paper, Seminar kit

\begin{abstract}
Abstrak. Tujuan kegiatan ini untuk menyediakan kebutuhan seminar (seminar kit) yang dewasa ini ramai diselenggarakan baik oleh Universitas Sumatera Utara (USU) maupun universitas lain. Metode yang digunakan yaitu memperkenalkan produk andalan eco-print yang bias diaplikasikan pada kertas dan kain. Produk eco-print yang diaplikasikan pada kertas daur ulang digunakan sebagai cover block-note ekslusif dan yang diaplikasikan pada kain digunakan sebagai bahan tas tote seminar. Keunggulan eco-print dibuat dengan menggunakan bahan alami tanpa
\end{abstract}

*Corresponding author at: Jl.Tri Dharma Ujung No.1KampusUSU, Medan, North Sumatra, Indonesia

E-mail address: arif5@usu.ac.id 
menggunakan bahan kimia dan desain yang diperoleh spesifik, tidak sama satu dengan yang lain. Kegiatan ini melibatkan dua mitra yang masing-masing sebagai penghasil kertas daur ulang (recycle paper) dan penjahit kain yang saat ini membuat tas tote. Hasil sementara yang bias ditampilkan telah ada order/ pesanan untuk keperluan seminar kit yang diperoleh melalui kegiatan pameran. Evaluasi kegiatan ini, Nauli Apik USU sebagai produsen seminar kit masih kewalahan dalam hal tenaga kerja karena semua masih dikerjakan secara manual dan merupakan keterampilan individu. Diharapkan di masa yang akan dating manajemen produksi harus diperbaiki.

Kata Kunci: Eco-print, Kain, Kertas daur ulang, Manajemen produksi, Seminar kit Received 15 January 2020 | Revised 20 February 2020 | Accepted 15 March 2020

\section{Introduction}

Scientific event such as seminar is a daily and a routine activity for teaching/ lecturer staffs at university, because it is one of dissemination media for introducing research or community service progress or results. The seminars can be held in the level of local, national, regional, even international depends on the audiences. The event could involve participants, presenters, or speakers with the number up to hundreds. To date, an intercontinental seminar with an international indexed proceeding (such as Scopus or Web of Science) has been becoming a trend. Some campuses particularly in Indonesia have been organizing such events because a direct impact is gained when the article has been published and accessed freely (open access). Universitas Sumatera Utara (USU) has been being a host, held and organized at least 40 national or international seminars since 2017 [1].

During the events there are a need to provide accomodation and consumption, along with seminar kits comprising of bag, book of abstract containing schedule, presentation titles and their presenters, block-note or scretch note, souvenir, and name-tag. The accommodation and consumption were usually available in the hotel where the events are held. However, the seminar kits were mostly provided by the organizing committees.

Professional bussiness for providing seminar kit is made of non wood, non wood derived products or recycle products with environmentally friendly are still rare up to now. Therefore, seminar, particularly international seminar, empower the business unit campus to provide the seminar kits. Business unit campus of "Nauli Apik" has been managed by department's staff (Department of Forest Products Technology) with the main managers originated from this team. The business unit was supported by Laboratory of Forest Products Technology that can organise workshop of saw milling 
and wood moulding. To date, business unit campus of "Nauli Apik" is not routinely running every day, unless the order for the seminar kits are accepted.

If in a seminar there is at least 100 participants and each of themgets one package of a seminar kit (consisted of four items: a bag, a block-note, a name tag, and a souvenir such as a pin or a key chain), there is 400 items of products can be provided by this business unit. If there are 2 events (a national and an international seminars) in a year for one campus, there will be 800 product items. Therefore, if for instance we targeted the market place is campuses within Medan city area (there is 84 campuses [2]), it will be 67,200 items of products needed. In other words, this business market place is very prospectus particularly in eco printing [3] with using natural colorant [4][5][6][7] including for providing seminar kit.

\section{Methods}

\section{a. Raw Materials}

Wood as the raw material must be available, because the products are based on wood, wood derived products, and recycle products with environmentally friendly. Wood for souvenir can be gained from thinning and pruning of trees or wood with low quality such as mahagony wood from community forest [8]. Wood derived products such as recycle paper, i.e.waste of reports, test paper, or draft can be obtained from campus. For plastics, they can be sorted manually according to type of the plastics [9] (usually it can be seen in the bottom of the package made of plastics, whether they are classified as $\mathrm{PP} /$ polypropylene, PE/polyethylene, or PS/polystyrene). Prior to use, the plastics have to be converted into particles, then blended and mixed with wood powder.

For early round, either own ideas or own products, we can apply principle of "SCM" (see, copy, and modify). Therefore, at the first stage going survey is needed by buying samples based on wood, wood derived products, or recycle products in the market for SCM.

\section{b. Target production}

In order to fulfill the target, "Nauli Apik" empowered equipment in laboratory for resulting product items. We employed saw milling and molding tools in Laboratory of Forest Products for producing souvenir items based wood. However, for bending molding, it is still needed for buying or renting a bending sawing. Probably, if the order of such items has been accepted, investment of the kind of tool is important. At present, this kind of the tool has not been needed yet. Planning in the early stage includes: 1) Making souvenirs made of wood branches; the design and pattern are made by teaching 
or lecturer staff from this project while the mass production is done by the partners; target of production is 300 pieces; 2) Recycling paper for block-note cover; target of production is 500 pieces; 3) Making stop-map made of recycles paper; target of production is 100 pieces; 4) Designing bag made of natural fiber; target of production is 100 pieces; 5) Making simple key-chains; target of production is 100 pieces.

Production was started from making design and prototype by lecturer staffs with the help of partners. Then, the mass production was done by the partners, testing/ evaluation of quality control by lecturer staffs, marketing and promotion by lecturer staffs with the help of partners, and selling by the partners. For production purposes, Laboratory of Forest Products Technology, which is equipped by sawing and molding machines for making prototype, supports as the workshop place. Mass production and chambering were carried out in partners' workshop (Mr. Arif Irwansyah), located at 'Usaha Pernik Kayu” Jalan Amaliun, Medan.

\section{c. Production Process}

Production process was described in detail in Figure 1 as follow:

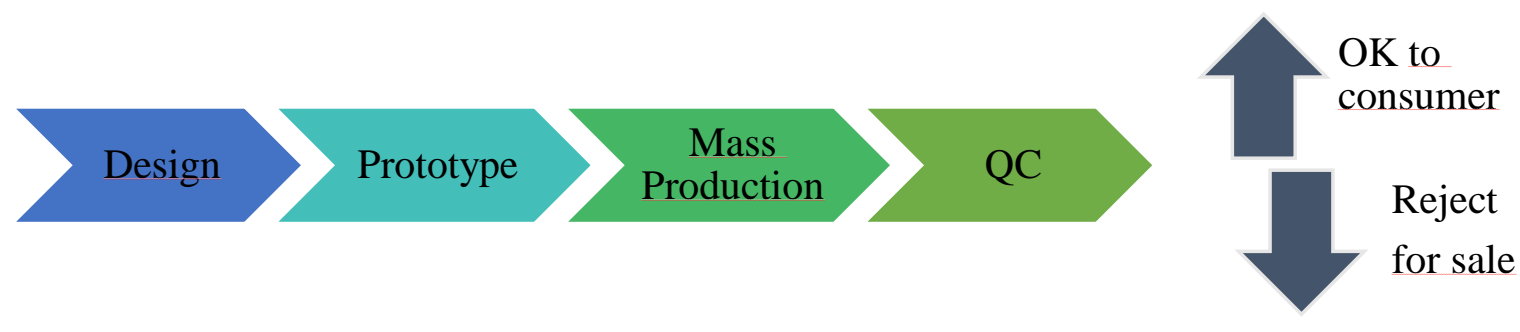

Figure 1. Diagram of production process

The design and prototype were made by lecturer staffs with the help of partners at Laboratory of Forest Products Technology. Mass production was taken place at the partners'workshop. Quality controlling was held by lecturer staffs using quality assurance using statistics methods. Products with loading purposes like paper bag should pass the testing of strength, which was undertaken for 3-5 replications.

\section{d. Management}

For the first year, effort for establishing and transformation from sporadic business becoming a professional one is the priority. Improvement of management was carried out on production planning (by the leader of this team) and accounting (by member of this team). For auditing and more professional management will be done in the second year by recruiting another member from Faculty of Economic and Business with concentration in management. Thus, good management and established business model will expect to be reached in the third year. 


\section{e. Marketing}

Marketing was carried out by the partners either directly or indirectly (online media). Community service team/ lecturer staff usually gets seminar flyer. According to the flyer, partners will contact seminar's organizing committee for seminar kit products marketing. The team promoted the benefit of seminar kits, because they are made from wood, wood derived products, or recycle products that environmentally friendly lead to making earth become sustainable. In the promotions, it was mentioned that the products were made and tested in laboratory in Faculty of Forestry, USU.

\section{f. Human Resources}

To date, a partner has been a fixed worker in "Nauli Apik" with salary IDR 500,000 per month (2018) and IDR 600,000 per month (2019). With scheme of development business program of intellectual property from campus, the salary will increase up to IDR 750,000 per month with additional bonus if the selling value is above the target.

\section{g. Tools}

Tools are available in Laboratory and Workshop of Forest Products Technology, such as equipment for sawing and wood molding. Workshop and chambering are also available in partners'place at Jalan Amaliun Medan. In the campus, there will be a show-room for exhibiting products made of "Nauli Apik USU", so that guests or visitors can visit, choose, and shop for the products. Contact person is also available.

\section{h. Financial}

Definition of $\mathrm{B} / \mathrm{C}$ (benefit to cost) ratio is a way or a procedure for identifying whether a business is beneficial, disadvantage, or loss. Therefore, $\mathrm{B} / \mathrm{C}$ ratio calculation is very important for knowing the advantage. The $\mathrm{B} / \mathrm{C}$ ratio is a measurement of comparison between revenue and Total Production Cost $($ Cost $=\mathrm{C})$. B means benefit or advantage while $\mathrm{C}$ means cost. Even though the calculation of $\mathrm{B} / \mathrm{C}$ ratio is based on interest rate, business of "Nauli Apik" does not apply it. In other words, the interest rate in this business is vanished. Therefore, calculation of IRR (Internal Rate of Return), a method for calculating investment which considers interest rate, is not accepted anymore.

$\mathrm{B} / \mathrm{C}$ ratio shows the benefits based on the spending cost. If the calculation of $\mathrm{B} / \mathrm{C}$ ratio is more than (>) 1 , the business is feasible and it should be continued. By contrast, if the calculation of $\mathrm{B} / \mathrm{C}$ ratio is less than $(<) 1$, the business is not feasible and it should be re-considered. These calculations determine whether the business is feasible, not feasible, or just to be enhanced.

The first capital is only IDR 10.000.000, which is expected to be enough because some of it is allocated for the workers' salary (in this case is for partners). Cash-flow, revenue from the benefits selling, and additional capital must be flown actively. 


\section{Results and Discussions}

\section{a. Results}

To date, business of "Nauli Apik" has become "Nauli Apik USU" because its prototypes of the products were made in Laboratory of Forest Products Technology, Faculty of Forestry, USU. Therefore mentioned products can be seen in Figures 2, 3, 4, 5,6 .

1. Recycle paper, as shown in Figure 2.
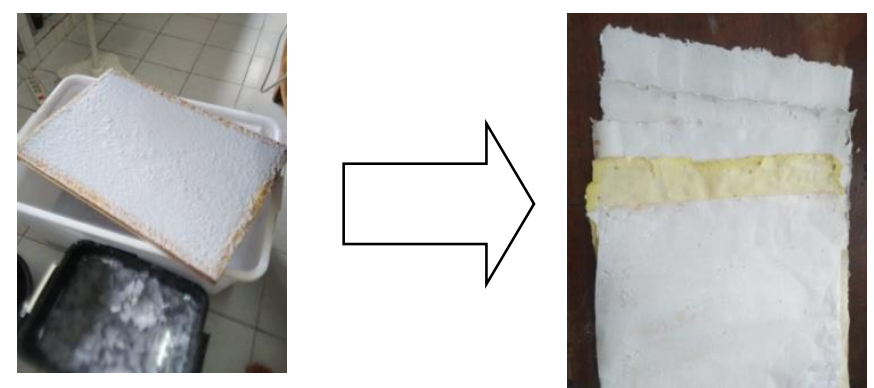

Figure 2. Recycle paper made of waste of paper

2. Cover of block-note with eco-printing technology, in Figure 3, similar with work of $[10]$
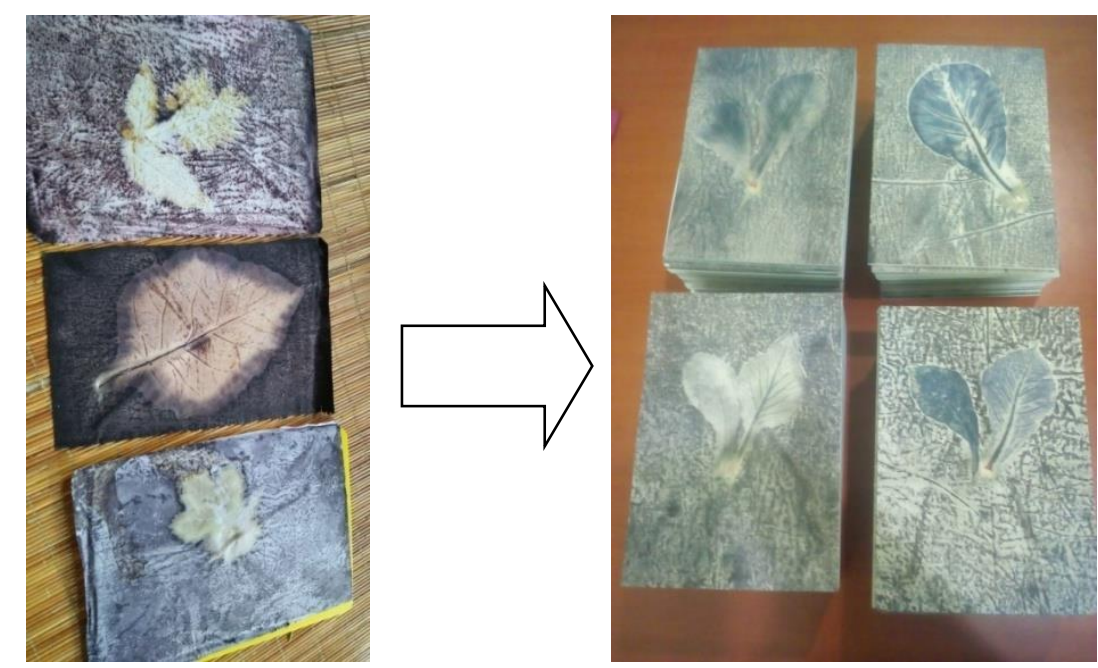

Figure 3. Recycle paper as media of eco-printing for block-note cover

3. Seminar bag (tote bag) with eco-printing decoration, as shown in Figure 4 


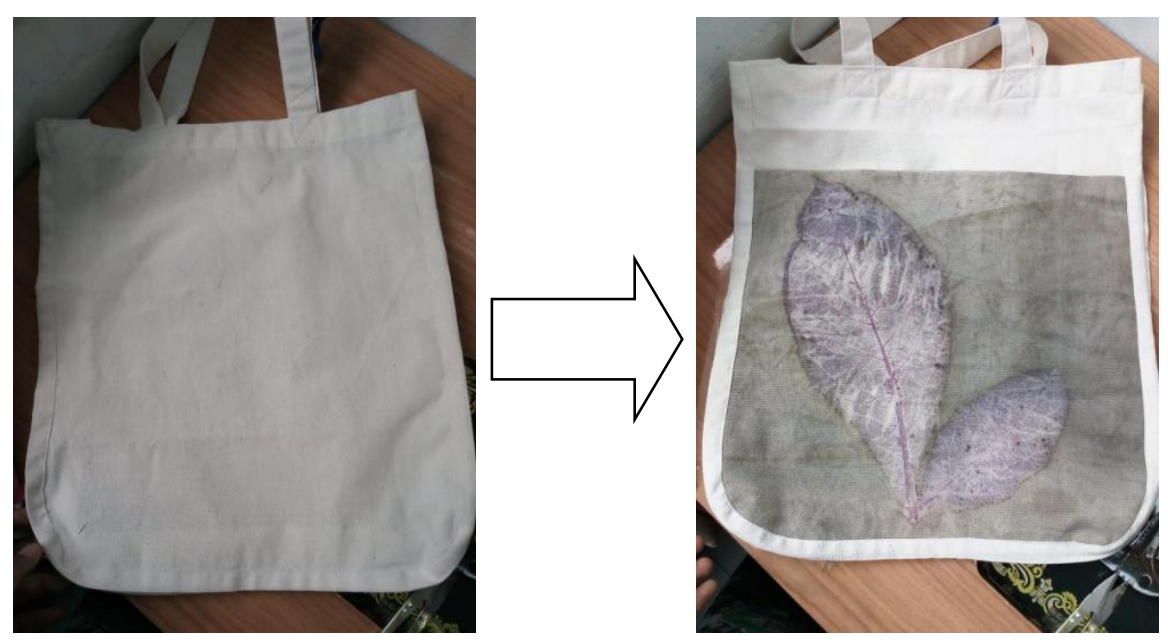

Figure 4. Tote bag for seminar bag with co-print decoration

4. Eco-print on goat leather for materials of wallet or pencil case, as shown in Figure 5.
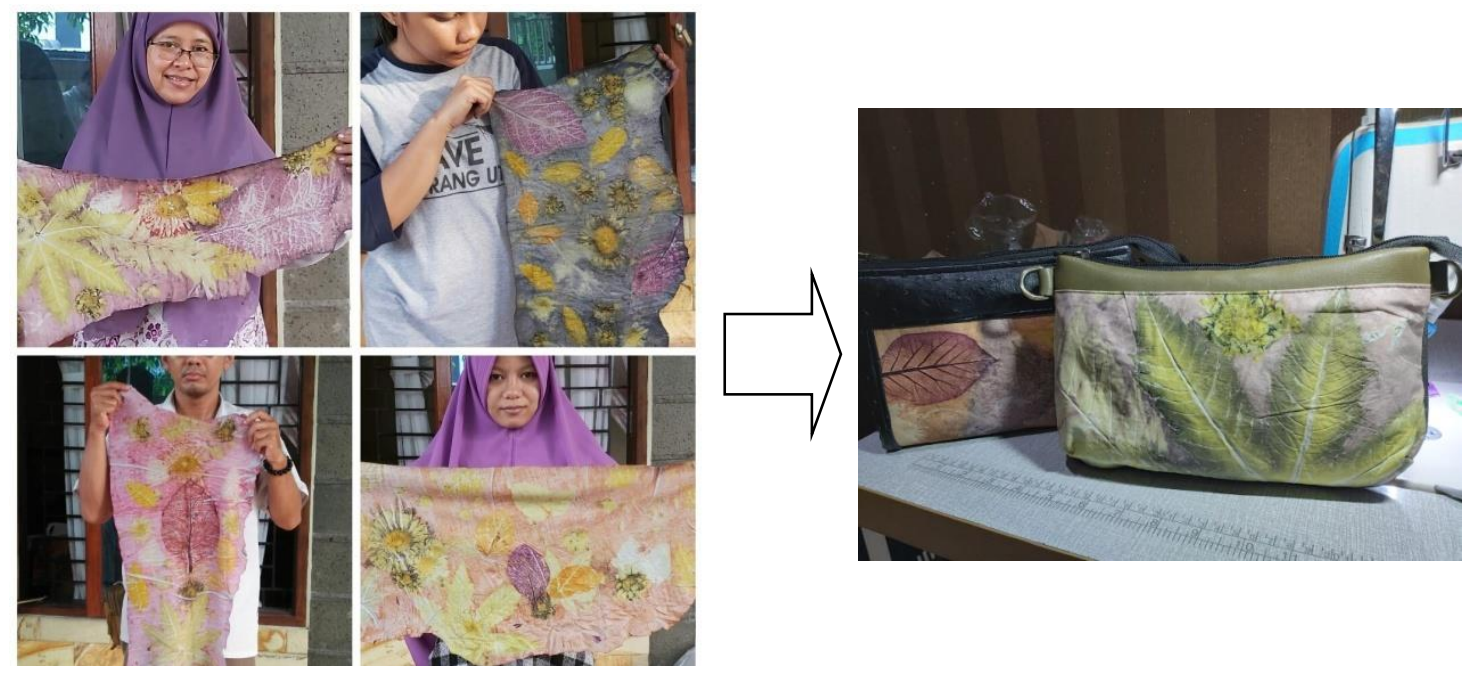

Figure 5. Wallet or pencil case made of goat leather for seminar souvenir

5. Eco-print on fabric for pencil case/veil/hijab/table top material, as shown in Figure 6.
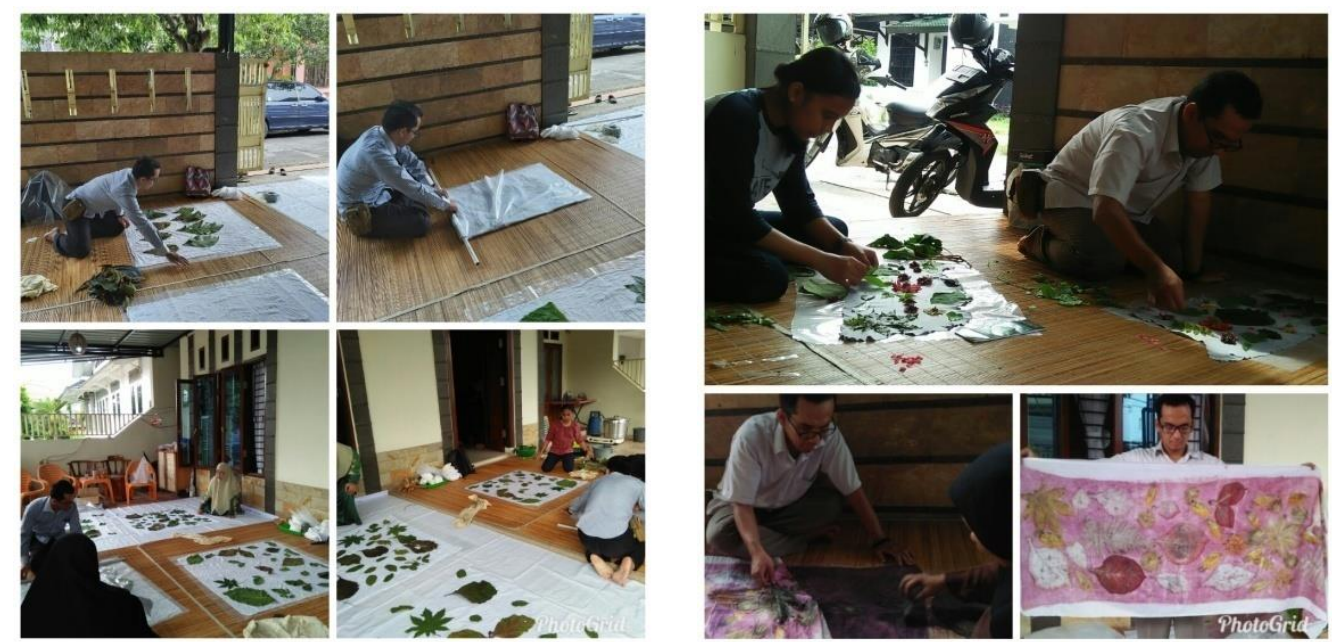

Figure 6. Eco-print on fabric for pencil case/veil/hijab/table top purposes 
Currently, "Nauli Apik USU" has been sold its products successfully (Figures 7, 8, 9, 10), such as: 1) Block-note with cover of recycles paper using eco-print decoration with the seminar information as shown in Figure 7. The 100 pieces of block notes cost IDR 500,000 .

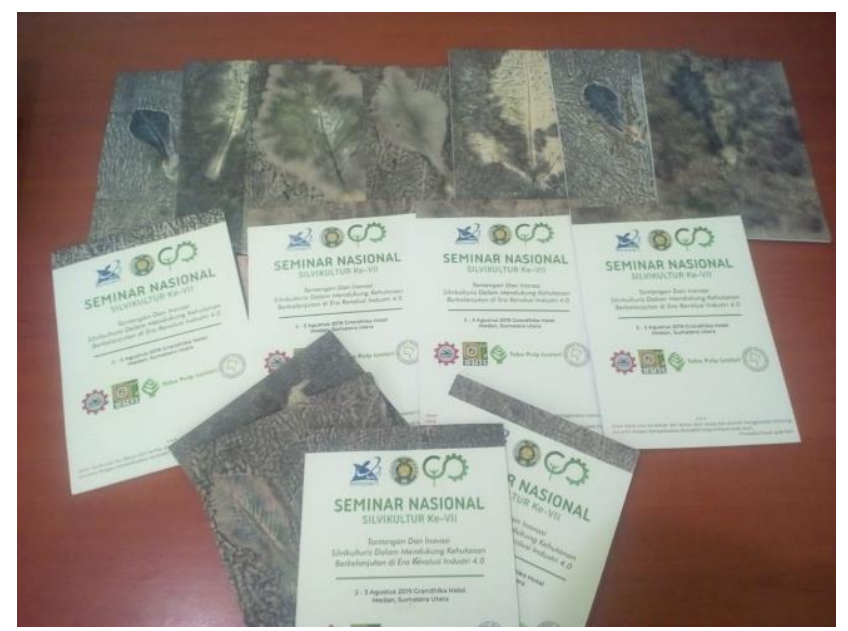

Figure 7. Block note with cover made of recycle paper and eco-print on it

2) Wood key-chains with name of the seminar on its face, the price of 100 pieces is IDR 500,000 as shown in Figure 8.

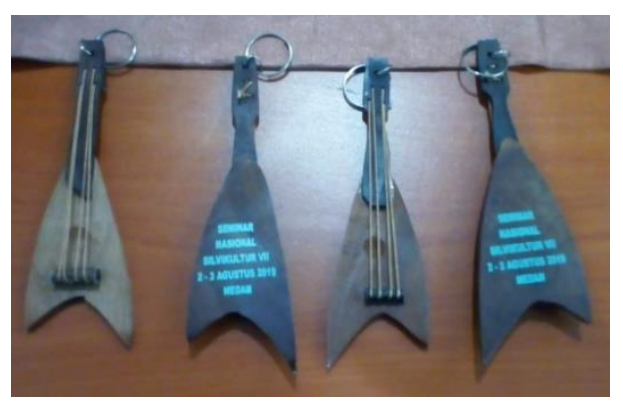

Figure 8. Key-chains made of wood for seminar souvenir

3) An eco-print on silk hijab (as a display product at exhibition) is sold for IDR 300,000 (Figure 9).

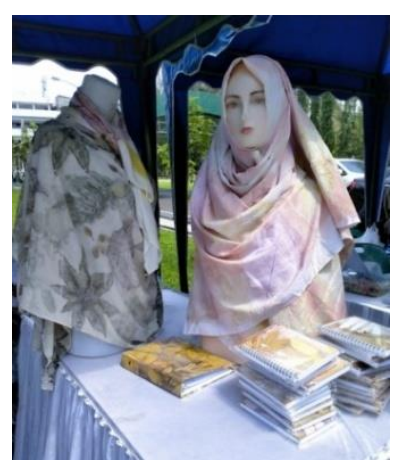

Figure 9. Hijab/veil made of silk with eco-printing 
4) Ten block-notes with eco-print on recycle paper (IDR 200,000) as shown in Figure 10.

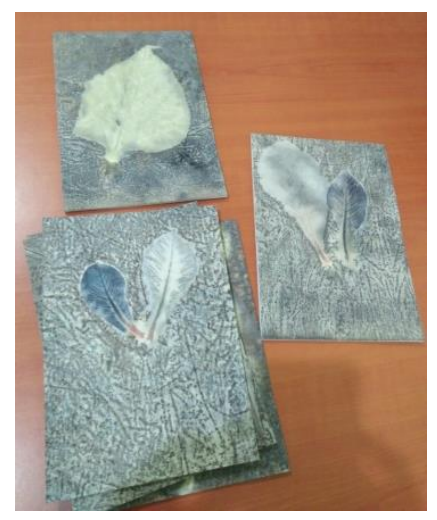

Figure 10. Block-notes with eco-printing cover made of recycle paper

Outputs have been made by "Nauli Apik USU" up to date are as follows: 1) "Nauli Apik USU" has been determined its main products namely eco-printing product particularly using recycle raw materials such as recycle paper, 2) "Nauli Apik USU" has had prototypes of the main products using materials originated of wood and wood derived products, 3) "Nauli Apik USU" has been carried out an exhibition at national seminar as the dissemination of this activity, as shown in Figure 11.

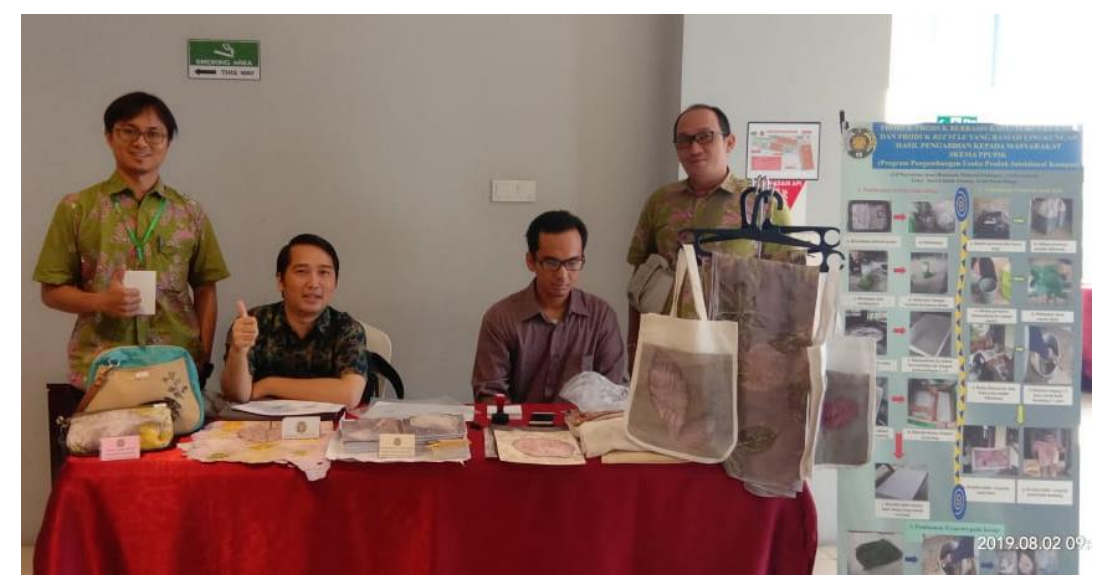

Figure 11. An exhibition at National Seminar of Silviculture at Grandhika Hotel Medan Furthermore, "Nauli Apik USU" has had a cash-flow from selling activity, as shown in Table 1. 
Table 1. A cash-flow of "Nauli Apik USU"

\begin{tabular}{llccc}
\hline \multirow{2}{*}{ No } & \multicolumn{1}{c}{ Item Product } & Base-price & Selling-price & Profit (bruto)* \\
\cline { 3 - 5 } & & \multicolumn{3}{c}{ (IDR) } \\
\hline 1 & $\begin{array}{l}\text { Block note with cover } \\
\text { made of recycle paper } \\
\text { and eco-printing (100 } \\
\text { pcs) @ IDR3000 }\end{array}$ & 300.000 & 500.000 & 200.000 \\
\hline 2 & $\begin{array}{l}\text { Wood key-chains (100 } \\
\text { pcs) @ IDR 2300 }\end{array}$ & 230.000 & 270.000 \\
\hline 3 & $\begin{array}{l}\text { Block note with cover } \\
\text { made of recycle paper } \\
\text { and eco-printing (without } \\
\text { script) (10 pcs) @ } \\
\text { IDR3000 }\end{array}$ & 30.000 & 200.000 & 170.000 \\
\hline
\end{tabular}

*Bruto (without worker salary)

For sum up, there are several planning to be conducted in the next stage. Firstly, mass production of tote bag is carried out by "Nauli Apik USU" because there are some organizing committee ordering this item. Secondly, research on quality control on "Nauli Apik USU" products using statistics will be applied. Thirdly, draft on intellectual property such as simple patent draft will be implemented, such as for recycle paper method and eco-printing on recycle paper method. Fourthly, writing of scientific article about this project for journal publications or presentations. Lastly, continuing production "Nauli Apik USU" products will be done out in order to enrich diversification of the seminar kit products.

\section{Conclusions}

Community service such of this work with the scheme of Development Business Program of Intellectual Property of Campus in providing seminar kit has the potential prospectus business. Production with variety in products items, particularly with environmentally friendly claimed, will open market share automatically, for instance during exhibition. Recommendation of this activity is fully supported by the university, thus this activity will be continued also for the beneficial of the university.

\section{Acknowledgments}

This community service activity was funded by NON PNBP Universitas Sumatera Utara, in accordance with letter of agreement of assignment for community service activity multi-years program, year of fiscal of 2019, number: 328/UN5.2.3.2.1/PPM/2019, date of May 20, 2019. 


\section{References}

[1] Ministry of Research, Technology and Higher Education Republic of Indonesia. 2013. Pangkalan Data Pendidikan Tinggi Kementerian Riset, Teknologi dan Pendidikan Tinggi. https://forlap.ristekdikti.go.id/perguruantinggi/homegraphpt (2013) [accessed on March 23, 2019].

[2] Universitas Sumatera Utara, Medan, Indonesia. 2017. USU Conference Systems. https://ocs.usu.ac.id/index/index/index (2017) [accessed on March 23, 2019].

[3] D. Nurcahyanti and U. Septiana, "Handmade eco print as a strategy to preserve the originality of Ria Miranda's design in the digital age". Mudra Journal of Art and Culture, vol. 33, no. 3, pp. 395-400, 2018. doi: 10.31091/mudra.v33i3.543.

[4] M. Rekaby, A. A. Salem, and S. H. Nassar, "Eco-friendly printing of natural fabrics using natural dyes from alkanet and rhubarb". The Journal of The Textile Institute, vol. 100, no. 6, pp. 486-495, 2009.

[5] O. E. Ismal, "Patterns from nature: contact printing". Journal of the Textile Association, pp. 81-91, 2016.

[6] M. Yusuf, M. Shabbir, and F. Mohammad, "Natural colorants: historical, processing and sustainable prospects". Natural Products and Bioprospecting, vol. 7, pp. 123-145, 2017.

[7] A. Gürses, 2019. Chapter 2. Sustainable colorants in The Impact and Prospects of Green Chemistry for Textile Technology, ul-Islam S and Butola B S (eds). The-Textile-Institute-Elsevier-Woodhead-Publishing. doi.org/10.1016/B978-0-08-102491-1.00002-2.

[8] R. Widyorini, K. Khotimah, and T. A. Prayitno, "Effect of temperature and hot treatment method to the physical property and quality of finishing of mahagony wood". Journal of Forestry Science, vol. 8, no. 2, pp. 65-74, 2014.

[9] B. Ruj, V. Pandey, P. Jash, and V. K. Srivastava, "Sorting of plastic waste for effective recycling". International Journal of Applied Sciences and Engineering Research, vol. 4, no. 4, pp. 564-571, 2015.

[10] I. S. Jeong and K. Y. Kang, "A study on scarf design using eco printing- focused on the researchers's works". JKCA, vol. 17, no. 11, 2017. 